\title{
Evaluation of Level of Utilization of Cervical Cancer Screening Services in Health Facilities in Nasarawa LGA of Kano State of Nigeria
}

\author{
NDIE E $\mathbf{C}^{1}$, MBA C J $\mathbf{J}^{2}$ \\ ${ }^{1}$ Department of Nursing Science, Ebonyi State University, Abakaliki, Nigeria \\ ${ }^{2}$ Department of Nursing Science, Bayero University Kano, Nigeria
}

\begin{abstract}
This study was undertaken to assess the utilization of cervical cancer screening services in health facilities in Nasarawa local Government area of Kano State. A retrospective study was carried out to determine the utilization of the services by checking the health facility's records from 2011-2014 with a checklist and workers were interviewed with an interview schedule. Data were collected and analyzed using Minitab. Results showed that the availability of cervical cancer screening is grossly low (4.8\%) in health facilities in Nasarawa LGA as only one secondary facility is offering the services. Pap smear and fine needle aspiration cytology were the only available screening services provided. $34 \%$ represents the highest number of clients who have utilized the services from 2011-2014 and majority of them (39\%) were within the ages of 31-40yrs. Majority of the respondents (86\%) said fear of outcome is one of the factors responsible for non-utilization while $51 \%$ said lack of awareness is another factor. In conclusion, the utilization of cervical cancer screening is very low. Public enlightenment targeting the women should be instituted. Cervical cancer screening services should be made available and affordable to women.
\end{abstract}

Keywords: Utilization, cervical cancer, screening services, health facility

\section{INTRODUCTION}

Cervical cancer is the second most common cancer in women worldwide only next to breast cancer. Globally, about 500,000 women acquire the disease annually and about $75 \%$ are from developing countries. It is the second most common global cause of deaths (about 300,000) from cancer in women after breast cancer, annually (Adesokan, 2014). In Nigeria it is the second commonest type of cancer in women and more prevalent in the Southern part of the country (Ogunbode OO, Ayinde OA 2011).

Until recently etiology of cancer of the cervix has not been clear but many studies have now linked cancer of the cervix with certain virus- Human Papilloma virus (HPV). Virtually all cervical cases (99\%) are linked to genital infection with certain strains of HPV. Types 16 and 33 actually lead to cervical cancer and become persistent as the HPV cells occupy the host cells. The persistence of viral DNA in the host cells ultimately result in the cervical changes leading to carcinoma (Adesokan, 2014). Known risk factors include early coiterche, multiple sexual partners, compromised immune system, high parity/multiparity, family history of cancer of the cervix, recurrent sexually transmitted infections and smoking of cigarettes. A male consort who in turn has had intercourse with multiple women also confers a significant risk.

Globally, women particularly those that live in developing countries suffer higher rates of morbidity and mortality from cervical cancer than previously noted. Each year approximately 10,000 women develop cervical cancer, and about 8,000 women die from cervical cancer in Nigeria (Airede, et al 2008). There are several socio-cultural practices, particularly in Northern Nigeria that promote the development of cervical cancer (Shehu, Sule, 2005). In Northwest Nigeria, 77\% of the population live below the poverty line and only $22 \%$ of females aged 15 years and above are literate. The median age at marriage is 14.6 years and $40.3 \%$ live in polygamous unions which are culturally and religiously acceptable and this gives room to a partner with multiple sexual partners (Shehu SM, Sule ST, 2005).

Ogunbode et al (2011) studied awareness and determinants of cervical cancer screening among market women, only $5.2 \%$ of the respondents have had previous Pap smear done. Similar study by 
Ayinde et al (2005) among female undergraduates in Ibadan showed that of those that are sexually active, only $8.3 \%$ of them had ever done a papanicolaou's smear. Interestingly, Aboyeji (2004) in a study found that, of those with knowledge of Pap smear, only $10(0.3 \%)$ had Pap smear test at least once previously. A study conducted by Nwobodo et al (2005) in Sokoto, among female health workers found out that only $4.4 \%$ of the respondents had availed themselves of screening. Another study carried out in Nnewi by Udigwe (2006), among female nurses found that only 5.7\% had ever undergone a Pap smear. Ezem (2007) also reported 7.1\% utilization of the services in a communitybased study. Feyi-Waboso et al (2005) in their study in Aba found out that only 32 women (16\%) had knowledge of cervical cancer, of which only $8 \%$ of them have had Pap smear performed on them.

The story is similar in other parts of the world, particularly developing countries. In a study in South Africa, in spite of knowledge of cervical screening and the availability of such services, the majority of women (87\%) from higher social and educational backgrounds did not undergo cervical screening (Parkin et al 2003). In Uganda Mutyaba et al found that $81 \%$ of women had never been screened. Of the male respondents, only $26 \%$ had partners who had ever been screened. In Botswana, in a study by Sankaranarayanan, et al (2010) Pap smear utilization was also limited among low-income women. Of the 18 women who had at least one Pap smear test in their lifetime, eight (44\%) had opportunistic testing as a result of having gynecological symptoms. Twelve women $(40 \%)$ had never had Pap smear tests. The purpose of cervical cancer screening is the early detection, diagnosis, and treatment of cancer precursor lesions and cancer (Saslow, et al. 2002).

Not many works are done on this topic in Nigeria; paucity of data also necessitated this study which will form a baseline for subsequent comparison and intervention. This study therefore attempts to provide useful information on the utilization of cervical cancer screening services in Health Facilities in Nasarawa Local Government Area of Kano State Nigeria.

\section{Methodology}

The research design for this study was an exploratory, descriptive retrospective survey study. A total of 21 Government owned health facilities were selected using purposive sampling technique from facilities in Nasarawa LGA for the assessment of utilization of cervical cancer screening services. A semi-structured questionnaire and check list was used for data collection. Split-half method was used to test the validity of the instrument. The correlation coefficient was 0.81 .

Nasarawa is a Local Government Area in Kano State, Nigeria. Its headquaters is located at Bompai, within the city of Kano State. It has an area of $34 \mathrm{~km}^{2}$ and a population of 596, 669 as at 2006 census. Nasarawa LGA is within the metropolis. The major tribes include- Hausa, Fulani, Yoruba, Ibo and few other tribes. Traditionally there is a district head and ward head who head the wards and district regions in the community. Also politically an executive Chairman who is assisted by the Vice Chairman heads the Council. There are 20 government health facilities in Nasarawa LGA which comprise of both primary and secondary.

Set of questionnaires were administered to the health personnel in charge of cervical cancer screening Units. The structured interview questionnaire were designed to explore the utilization of available cervical cancer screening services in various health facilities in Nasarawa LGA. A check list was also used to audit utilization of the screening services.

Ethical approval was obtained from Hospital Management Board Kano State to carry out the study. Verbal informed consent was sought from respondents, nature of research duly explained to participants. Confidentiality of information was guaranteed. The completed questionnaires were collated and analyzed using computer Minitab.

\section{RESULTS}

Table I. Number of women who Utilized The Services From 2011-2014

\begin{tabular}{|l|l|l|}
\hline No of patients who have utilized the services & Frequency & Percentage (\%) \\
from 2011-2014 & & \\
\hline 2011 & 475 & 15.3 \\
2012 & 655 & 21.1 \\
2013 & 763 & 24.6 \\
2014 & 1205 & 38.9 \\
\hline TOTAL & 3098 & 100 \\
\hline
\end{tabular}


Evaluation of Level of Utilization of Cervical Cancer Screening Services in Health Facilities in Nasarawa LGA of Kano State of Nigeria

The results of utilization cervical cancer screening show that only 3098 women utilized the services from 2011- 2014 in a period of 4 years. The results also show that ne number increases as the year go by. The least number was in the year 2011 while the highest was in2014

Table 2. Effect of Age And Marital Status on Utilization of The Services

\begin{tabular}{|l|l|l|}
\hline VARIABLE & Frequency & Percentage (\%) \\
\hline $31-40$ & 983 & 31.7 \\
$41-50$ & 937 & 30.2 \\
$51-60$ & 684 & 22.1 \\
$61-70$ & 345 & 11.1 \\
$71-80$ & 75 & 2.4 \\
$81-90$ & 46 & 1.5 \\
$91-100$ & 28 & 1 \\
\hline Marital Status of the patient & & \\
\hline Single & 5 & 0.2 \\
Married & 2735 & 88.3 \\
Divorced & 358 & 11.5 \\
\hline TOTAL & 3098 & 100 \\
\hline
\end{tabular}

Table 2 above indicates that the highest percentage of women $(31.7 \%)$ who utilized the services falls within the ages of $31-40 \mathrm{yrs}$ while $30 \%$ are within the ages of $41-50$. Only $1.1 \%$ are within the ages of 91-100 yrs. Majority (88.3\%) of them are married while $11.5 \%$ are divorced and only $0.2 \%$ are single.

Fig 1- Reasons for Sreening

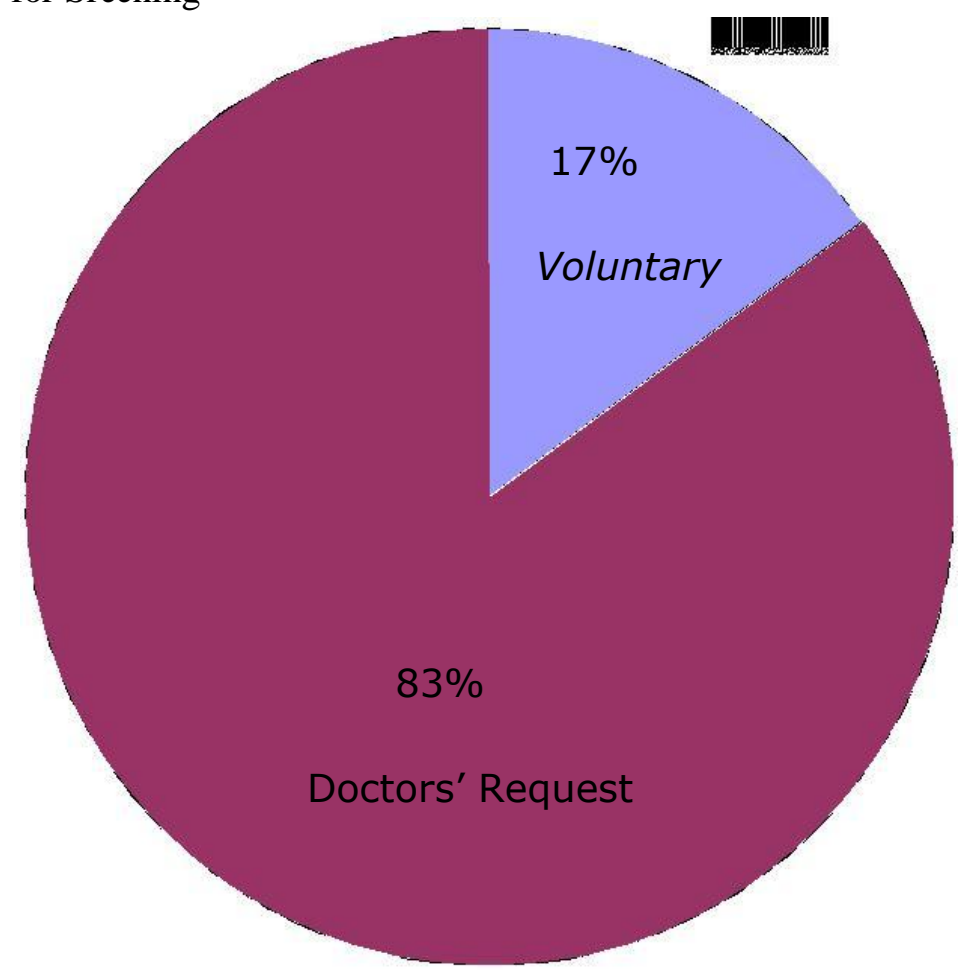

From fig 1 above shows that majority (83\%) of the clients who utilized the screening services did so on doctors' request while the remaining $17 \%$ did so voluntarily.

Table 3. Number of women Who Tested Positive From 2011-2014.

\begin{tabular}{|l|l|l|}
\hline Variable & Frequency & Percentage $(\%)$ \\
\hline 2011 & 12 & 18.2 \\
2012 & 17 & 25.8 \\
2013 & 12 & 18.2 \\
2014 & 25 & 37.8 \\
\hline TOTAL & 66 & 100 \\
\hline
\end{tabular}

The above table shows that out of 3098 women who utilized the service 66 of them tested positive from 2011-2014. 
Table 4- Opinion Of Clinic Workers On Reason For Poor Utilization Of The Services.

\begin{tabular}{|l|l|l|}
\hline Variable & Frequency & Percentage (\%) \\
\hline Lack of access to services & 27 & 24 \\
Fear of outcome & 45 & 41 \\
Exposure of private part & 23 & 20 \\
Lack of physicians referrals & 23 & 20 \\
Exposure to other diseases & 36 & 32 \\
Lack of awareness of services & 51 & 45 \\
\hline
\end{tabular}

From the above table, fear of the outcome and lack of awareness i.e. $41 \%$ and $45 \%$ respectively are the major factors that inhibit utilization while $32 \%$ and $24 \%$ represent exposure to other diseases and lack of access to services. Other factors include fear of harm and exposure of private parts represent $20 \%$ and $20 \%$ respectively.

\section{DISCUSSION}

This study is on the utilization of cervical cancer screening services in Health facilities in Nasarawa LGA of Kano State. The screening services that are available and being utilized in the Health facility are Pap smear and fine needle aspiration cytology. From 2011-2014 only 3098 women utilized the service which is very low, though the number increases as the year go by. This can be attributed to increased level of awareness to cervical cancer screening. Findings also show that the highest number of patients/clients (31.7\%) who have utilized the services are between the ages of 31-40yrs of age. This is similar to the result obtained by Anyebe et al in Zaria. Majority of the clients (87.2\%) who utilized the services are married while 5.3\% are single. This is similar to the study conducted by Ezem B.U. in South East Nigeria. The highest percentage (35\%) that tested positive to cervical cancer was in 2014. This may be attributed to the number of clients who utilized the services at that time. Majority of the clients (85\%) who utilized the services were screened using the Pap smear method while the remaining $15 \%$ utilized the fine needle aspiration cytology.

Majority (83\%) of the clients who were screened did so on doctors' prescription while the remaining (17\%) was voluntary. This is contrary to a study conducted by Ogunbode in South West Nigeria where majority of the clients $(80.6 \%)$ who utilized the services did so voluntarily. Lack of physician's referrals and ignorance about location of service centers were the two most frequent reasons for failure of utilization. This is similar to a study conducted by Adefaye in Sagamu while Aboyiji et al found that fear of outcome and exposure of private parts were factors responsible for poor utilization.

\section{CONCLUSION}

The utilization of cervical cancer screening services are very low. These should be addressed in order to reduce the incidence of cervical cancer in Nigeria. A well coordinated cervical cancer screening programme targeted at risk groups (e.g. elderly and sexually active women) should be instituted. Efforts should be made to increase the proportion of spontaneous screening and reduce that of opportunistic screening. Finally, information on cervical screening should be given regularly to women.

\section{REFERENCES}

[1] Aboyeji PO.(2004) Knowledge, attitude and practice of cervical Smear as a screening procedure for cervical cancer in Ilorin, Nigeria. Trop J. Obstet gynae ; 21:114-117.

[2] Adefuye PO(2006). Knowledge and practice of cervical cancer Screening among female professional health workers in sub-urban district of Nigeria, Nig Med Pract ; 50; 19-22.

[3] Airede LR, Onakewhor JUE, Aziken ME, Ande ABA, Aligbe JU.(2008) Carcinoma of the Uterine Cervix in Nigerian Women: The Need to Adopt a National Prevention Strategy. Sahel Medical Journal. ;11(1):1-11.

[4] Anyebe, E.E, Opaluwa S.A.Muktar, H.M, Philip, F.(2014) Knowledge and Practice of Cervical Cancer Screening among Nurses in Ahmadu Bello University Teaching Hospital Zaria. Research on Humanities and Social Sciences ISSN (Paper) 2224-5766). Vol 4, No 27,

[5] Ayinde OA, Ogunbode OO.(2005) Determinants of cervical cancer Knowledge and its utilization of screening among a Nigeria female population. Trop J. Obstet Gynae ; 22:21-24. 
[6] Ezem BU(2007) Awareness and uptake of cervical cancer screening In Owerri, South-Eastern Nigeria. Ann Afri Med ; 6:94-98.

[7] Ferley J, Bray F, Pisani P, Parkin DM. Globocan (2005): Cancer Incidence, mortality and prevalence worldwide. Lyon: IARC press; .

[8] Feyi-Waboso PA, Kamanu C, Ajuka C.(2005) Awareness and risk Factors for cervical cancer among women in Aba, South-Eastern Nigeria. Trop J. Obstet Gynae ; 22:25-26.

[9] Adesokan F O O(2014): Reproductive Health for All Ages; Bosem Publishers Nig. Ltd;

[10] Gharoro EP, Ikeanyi EN.(2006) An appraisal of the level of awareness and utilization of the Pap smears as a cervical cancer screening test among female health workers in a tertiary institution. Int J Gyneacol Cancer ; 16:1063-8.

[11] International Agency for Research on Cancer (IARC)(2005). Handbooks of Cancer Prevention: Cervix Cancer Screening. Vol. 10. Lyon, France: IARC;

[12] Mutyaba T, Mmiro FA, Weiderpass E.(2006) Knowledge, attitudes and practices on cervical cancer screening among the medical workers of Mulago Hospital, Uganda. BMC Medical Education. ; 6:13.

[13] Parkin DM, Ferlay I, Hamdi- Cherif M, et al (eds)(2003). Cancer in Africa: Epidemiology and Prevention LARC Scientific Publications No. 153. IARC Press Lyon,

[14] Parkin DM, Whelan SL, Ferlay J, Storm H.(2005) Cancer Incidence in Five Continents, vols. IVIII. IARC Cancer Base no. 6. Lyon, France: IARC Press,.

[15] Ries L, Harkins D, Krapcho M, (2006). SEER Cancer Statistics Review, 1975-2003: National Cancer Institute. Bethesda, MD: National Cancer Institute; Rankaranarayanan R, Thara S, Ngoma T, Naud P, Keita N.(2010) Cervical Cancer Screening in the Developing World. In: Finkel, M. (eds). Public Health in the 21st Century, 2(12), 231-244.

[16] Saslow D, Runowicz CD, Solomon D, et al(2002). American Cancer Society guideline for the early detection of cervical neoplasia and cancer. CA Cancer J Clin ; 52:342-362

[17] Shehu SM, Sule ST,(2005) Cervical cancer burden in Zaria Proceedings of the annual scientific meeting of the Association of Pathologists in Nigeria, Lagos .

[18] Nwobodo EL, Malami SA (2005). Knowledge and practice of cervical Cancer screening among female health workers in Sokoto, North Western Nigeria, Niger Postgrad Med J. 12:255-257.

[19] Ogunbode OO, Ayinde OA (2005). Awareness of cervical cancer and Screening in a Nigerian female market population. Arm Afr Med ; 4:160-163.

[20] Udigwe GO(2006). Knowledge, attitude and practice of cervical Cancer screening (Pap smear) among female nurses in Nnewi, South Eastern Nigeria. Nig J. Clin Pract ; 9:40-43 